\title{
Demand for Islamic Pension Funds in Indonesia: An Exploratory Study
}

\author{
Rahmatina A. Kasri ${ }^{1 *}$, Banu M. Haidlir¹, M. Amin², M. Budi Prasetyo ${ }^{1}$ \\ ${ }^{1}$ Faculty of Economics and Business, Universitas Indonesia \\ Email: rahmatina@ui.edu \\ ${ }^{2}$ Indonesia Financial Services Authority, Jakarta, Indonesia
}

\begin{abstract}
Pension fund is a financial sector that provides a range of benefits, not only to the participants but also to the country's economy. This applies to both conventional and Islamic pension funds. In Indonesia, although Islamic pension fund has not grown as fast as other Islamic financial sectors, many believe that the majority of Indonesian people actually interested in participating in Islamic pension plan. Therefore, the main purpose of the study is to explore and determine the preference/demand for Islamic pension funds in Indonesia. With this perspective, a survey was conducted in six major cities in Indonesia: Jakarta, Bandung, Surabaya, Makassar, Medan and Balikpapan, and involved 200 respondents. Halal purchase intention framework and exploratory factor analysis are employed to analyze the primary data obtained. Based on the findings, more than $70 \%$ of the respondents are interested to have an Islamic pension plan. Thus, demand for Islamic pension fund is relatively high in Indonesia. Further analysis also suggests that marketing and religiosity are the main determinants for purchasing or joining the Islamic pension plan schemes. Authorities and market players should therefore consider these factors in their strategy to accelerate demand and development of IslamicPension Funds in the country.
\end{abstract}

Type of Paper: Empirical

Keywords: Islamic pension fund; demand for Islamic financial product; halal purchase intention; consumer behavior; Islamic economics and finance

\section{Introduction}

Pension fund is a financial institution which manages assets as well as implement investment programs to provide the retirement benefits for its members and investors. The benefits provided by the fund vary, including allowing the members or investors to have fixed income and investment instruments that may earn return in the future (Scott, 1988; Blake, 2006). This is important for investors as they will experience productivity deficiency, income forfeit, and hence less purchasing power in their retirement ages. Pension fund may help them to resolve those issues. Furthermore, from macro-economic perspective, the existence of welldeveloped pension fund industry will be able to promote economic advancement, maintain 
financial system stability and complement banking system to distribute fund to the real sectors of economy (Mayer, Schoors and Yafeh, 2013). In addition, the existence of pension funds in a country is a tenet for guaranteeing life of an aging population (Panetta, 2006).

From the Islamic point of view, the concept of pension funds is very much in line with Islamic teachings. Islam strongly advocates Muslim to conserve and set aside some of his/her income for future use, especially when a Muslim has entered unproductive age. ${ }^{1}$ Muslims are also expected to prepare the next half of their life through incorporate frugal attitude into their lifestyle so that the needs of their future life can be sustainably fulfilled. ${ }^{2}$ Moreover, Islamic pension fund program is also in line with the concept of maqashid al-shari'ah, especially the purpose to protect property (maal) and posterity (nasl), since it allows Muslims to invest in shari'ah instruments/assets (Chapra 2008, Manjoo 2012). Apart from that, history of Islam shows that the provision of state pensions, especially to soldiers and widows, has been widely practiced since the reign of Caliph Umar bin Khattab (El Ashker and Wilson, 2005). Thus, it is safe to say that Islamic pension fund is necessary for Muslims to perform financial planning and wealth management.

Empirically, however, the development of Islamic pension fund institutions in Muslim countries have been relatively discouraging. For instance, Indonesia is the world's largest Muslim country but the total number of financial institutions that offer Islamic pension funds products is not ample, despite the issuance of fatwa related to the Islamic pension funds in $2013 .{ }^{3}$ The total Islamic pension funds' assets were very small compared to the industry's assets, which was only IDR 206.59 trillion (OJK, 2014), which leads the OJK to incorporate statistical reporting performance of Islamic pension funds with that of conventional counterparts. A survey conducted by OJK shows that only about $28 \%$ of Indonesian people know about Islamic pension funds. The survey also suggested that underdevelopment of both conventional and Islamic pension funds industry in Indonesia is allegedly influenced by several factors including low public awareness, regulation, and social structure (OJK, 2015).

Hence, notwithstanding the encouragement of using Islamic pension fund, the supply is very much low and the demand is unknown. The supply side has been encouraged by government interventions. However, understanding the demand side is urgent, since in that way, the supply side can also be incentivized to develop themselves. This leads to an intriguing question of how is the demand for Islamic pension funds in Indonesia. This study aims to explore the preference of consumers on the Islamic pension funds in Indonesia. Moreover, this study examined the determinants of purchase intention of Islamic pension funds in Indonesia.

Following the introductory section, this study is organized as follows. Section 2 reviews some related literature and followed by research methodology in the Section 3. Section 4 and Section 5 elaborate results and discussion respectively. Finally, Section 6 concludes and provides some recommendations from the study.

\footnotetext{
${ }^{1}$ See, among others, QS An-Nisa: 9, Al-Baqarah: 266, Al-Hasyr: 18 and Ad-Dhuha: 4

${ }^{2}$ Hadith Narrated by Tirmidhi, Baihaqi and Ahmad.

${ }^{3}$ Bank Muamalat Indonesia, Bank Rakyat Indonesia, Bank Negara Indonesia, Allianz, and Manulife.
} 


\section{Literature Review}

Despite importance of Islamic pension funds, as briefly explained in the previous section, very few studies attempt to determine and analyze preference/demand for Islamic pension funds in contemporary Muslim countries. The underdevelopment of Islamic financial sector in the world might be blamed for this issue. This can be seen from the fact that the current Islamic pension fund industry only grows in Malaysia and Pakistan (Arafa, 2014). On the other hand, in other Islamic countries such as Indonesia, the sector is still in the early stages of development. The cause might be related to the difficulty to measure the demand of Islamic financial products in general and Islamic pension funds. However, with some adjustments, it is possible to utilize halal purchase intentions concept in consumption of halal products (i.e. food, fashion, etc) - which have some similarities with Islamic financial products-- to find out consumers' preferences/behavior toward Islamic pension funds.

Research on the purchase intention is mostly done in halal food industry, in which the concept of halal and haram has implications for whether a food can be consumed or not by a Muslim (see, for example, Awan et al., 2015 and Azam 2016). Other halal products increasingly studied are cosmetics (Rahmat et al 2015), fashion (Hassan and Harun, 2016) and Islamic financial products (see, among others, Altaf et al 2017). The literature has documented various factors that influence the purchase intention of halal products, such as knowledge, halal awareness, religiosity (religious belief), personal societal perception, product reputation, and Islamic finance product marketing.

Awan et al. (2015) examined determinants of purchase intention to consume halal food in Pakistan. The study suggests that knowledge and halal awareness are the main determinants of purchase intention for halal food. Those include consumers' knowledge of halal and haram concept in sharia and their concern for the necessity to consume halal food and avoid the haram one. Similar conclusions are also suggested from the study of Rahman et al. (2015) in Malaysia.

Apart from halal awareness, other factor that affects the purchasing intention of halal food is consumer religiosity or religious belief. According to Shaari and Arifin (2009), behavior of a person is greatly influenced by his/her value. Consequently, two individuals with different foundations might act differently. The more religious a consumer, the stronger he/she will avoid various activities and behaviors that are contrary to his/her religious values. This is also applicable in the case of meals consumption (Schneider et al., 2011, Azam 2016), fashion (Hassan and Harun, 2016) and Islamic banking products (Altaf et al. 2017). Thus, many marketing studies related to consumer behavior locate religious beliefs as one of the explanatory factors.

Halal marketing, halal certification and personal societal perception are also recognized as measurements for the intentions of Muslim communities in consuming halal products/services. In marketing, the tendency to buy and consume a product is strongly influenced by effort, form, aggressiveness and creativity of producers in selling their products. Muslim communities who are aware of halal food and have high commitments to Islamic values may not want to consume foods where the halal status is unclear.

Study of Azam (2016) found that the Saudi Arabian Muslim consumers are willing to consume food produced by non-Muslim manufacturers if the products are certified as halal. Thus, this 
locates the importance of halal certification attached to the product. In addition, in the context of Eastern/Asian societies, people's perception towards the halal products/services often influences their consumption behavior as they will usually feel comfortable to behave in accordance with the norms of the community they live in. The abovementioned factors have been used in previous studies of halal purchase intensions, such as Awan et al. (2015) in Pakistan and Rahman et al. (2015) in Malaysia.

The concept of halal purchase intention explained above is suitable to measure the tendency of people in choosing Islamic financial products such as Islamic pension fund. From the shari'ah point of view, halal food and Islamic pension products have many similarities. For instance, both products have a clear halal-haram barrier line. However, in financial products, the halalharam status of the product is determined by more complex considerations than food, such as product design, ways to obtain the product, transaction mechanism, shari'ah scholars' opinions, and so on. Therefore, this study argues that the framework of consumer behavior theories that have been widely used in halal food, with some adjustments, can be used to determine the tendency of Muslims in using Islamic pension funds product. Furthermore, based on the literature above, the study hypothesized that preference/demand for Islamic pension funds in Indonesia has positive relationships with religious beliefs, halal awareness, reputation of pension funds, personal societal perception and halal marketing.

\section{Research Methodology}

This study attempts to examine the purchase intention and measuring the preference/ demand of Muslim customers on Islamic pension funds in Indonesia. The perception and purchase intention for the Islamic pension program is developed based on modification of the framework proposed by Awan et. al. (2015), as summarized in Figure 1. There are five factors that potentially affect the purchase intention, namely (i) religious beliefs (RB; spiritual values and religiosity set behaviour standards); (ii) halal awareness (HA; awareness regarding halal/haram status of Islamic products) ; (iii) reputation of pension funds (REP; shari'ah label and existence of shari'ah supervisory board); (iv) personal societal perception (PSP; social influence towards one's behaviors); (v) and halal marketing (HM; marketing conducted by Islamic financial corporates). Apart from the aforementioned variables, knowledge (KNOW; knowledge regarding Islamic financial principles and Islamic pension funds) is also used as a determinant variable since it is believed to affect the purchase intention (PI). The factors were subsequently translated into 20 questions and allegedly have positive correlation with the purchase intention. The questions were arranged Using Likert $1-6$ scales, where 1 equals to strongly disagree and 6 equals to strongly agree perception.

To measure the purchase intention, a set of questionnaires was constructed based on the framework above and in harmony with the theory mentioned in the literature section. Six major cities in Indonesia were selected as the region of studies (survey location), namely Jakarta, Bandung, Surabaya, Medan, Makassar, and Banjarmasin. They were chosen not only because of their representativeness as business/economic centers in Indonesia, but also because they were considered to have a relatively large potential for Islamic pension funds as indicated by the existence of Islamic pension funds institutions and the large percentage of the Muslim population in these cities. The respondents used were Muslim workers who can be divided into three categories, namely self-employed, private employees and educators (lecturers/teachers/ da'i). 


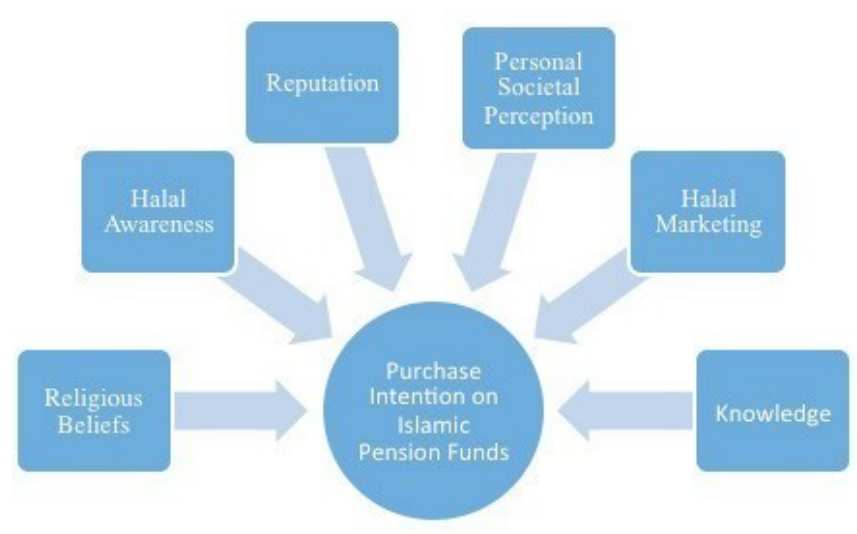

Figure 1. Framework to Measure Purchase Intention for Islamic Pension Funds

The sampling method used in this study was quota sampling, where respondents were opted systematically until the quota is fulfilled. The number of respondents obtained is 200 people and the distribution of respondents for each city were determined according to the percentage of Muslim populations in the cities. Thus, in the final sample, there were 100 respondents from Jakarta, 26 respondents from Bandung, 31 respondents from Surabaya, 18, 14 and 10 respondents from Medan, Makassar, and Banjarmasin, respectively. Additionally, in line with the purpose of this study, most of the respondents were still in productive age and have a long working time to retire.

In analyzing the results, the study utilizes descriptive statistics to measure the preference of consumers on Islamic pension funds. Furthermore, factor analysis and regression were used to examine the purchase intention on Islamic pension funds and subsequently estimate the determinants of demand for the Islamic financial product. ${ }^{4}$

\section{4. $\quad$ Results}

\subsection{Profile of respondents}

This study categorized the respondents according to their sex, educational background, marital status, and occupation. First, on sex category, the findings show that $63.21 \%$ of respondents are male and the remaining $36.79 \%$ of them are women. Second, on educational background, $50.94 \%$ of respondents hold a bachelor degree, whilst $28.77 \%$ of them have high school education background. Third, in terms of marital status, $63.21 \%$ of respondents are married, $34.43 \%$ are unmarried and the remaining $2.36 \%$ are divorced. Fourth, in terms of occupation, $62.26 \%$ of the respondents work as a private employee, while the remaining $25.94 \%$ of them are entrepreneurs. Only around $11.79 \%$ of them work as educators (lecturers/teachers/da'i).

\footnotetext{
${ }^{4}$ Since descriptive, regression and factor analysis are commonly used in quantitative studies, including the halal purchase intention studies, the methods are not elaborated in this paper. For more discussion about the techniques, please refer to standard (multivariate) statistics text books such as Field (2009) and Hair (2013) as well as the articles discussed earlier.
} 
The survey results also suggest that majority of respondents $(69.81 \%)$ are categorized under lower middle-class income who have IDR 1 - 5 million income per month. However, the increase in income is expected as they are still young and in the productive age. Furthermore, $17.45 \%$ of the total respondents are categorized in the middle class with IDR 5 - 10 million per month income level. Finally, only $2.36 \%$ of them have income above IDR 20 million per month. All things considered, the respondents involved in this survey are well-educate young people who, most of them, are still under the lower middle-class cohort with IDR 1 - 5 million income level and expected to have increase of income in the near future.

\subsection{Preference on Islamic pension funds}

This study found that majority of respondents have not involved in any pension fund plans. Only $30.66 \%$ of respondents have had a conventional pension program, whilst the rest $63.34 \%$ have never touched the same. The penetration rate of pension funds is even worse for the Islamic one. The results indicate that only about $3.3 \%$ of respondents are involved in Islamic pension program, while the rest of $96.7 \%$ have not followed the same. These findings indicate a very low penetration of Islamic pension funds in Indonesia.

Table 1. Level of interest to participate in Islamic pension programme

\begin{tabular}{lll}
\hline Regions & Interested & Not Interested \\
\hline Jakarta & $80.61 \%$ & $19.39 \%$ \\
Bandung & $84.62 \%$ & $15.38 \%$ \\
Surabaya & $74.19 \%$ & $25.81 \%$ \\
Medan & $55.56 \%$ & $44.44 \%$ \\
Makassar & $64.29 \%$ & $35.71 \%$ \\
Banjarmasin & $70.00 \%$ & $30.00 \%$ \\
\hline
\end{tabular}

Despite the survey results, majority of the respondents are interested to participate in Islamic pension program (see Table 1). On average, $72 \%$ of respondents expressed interest in this Islamic financial product. The biggest interest comes from respondents who live in Bandung $(84.62 \%)$ and Jakarta (80.61\%). On the other hand, Medan (55.56\%) and Makassar $(64.29 \%)$ become the cities with the lowest level of interest to involve in Islamic pension program.

A deeper investigation is performed to explore the reasons why respondents have never participated in a pension plan. The results suggest that $42.66 \%$ of respondents do not familiar with pension program and $30.77 \%$ of them claimed it does not even appear in their mind to participate in the program. Interestingly, the results also indicate that $15.38 \%$ of respondents clearly stated that they are not interested to participate in the pension program.

\subsection{Purchase intention and determinants on Islamic pension funds}

Table 2 highlights the result of correlation and Factor Analysis. The numbers highlighted are those with correlation over 0.5 , which indicates the high correlation between the two variables. The results show a positive correlation on all variable pairs, where all the correlations are statistically significant as indicated by high t-statistic and p-value. These results confirm the hypothesis proposed by study. Overall, however, halal marketing (HM), reputation (REPUT) 
and religious beliefs $(\mathrm{RB})$ are found to be the strongest factors positively correlated with purchase intention on Islamic pension program.

Table 2 Correlation Matrix

\begin{tabular}{|c|c|c|c|c|c|c|c|}
\hline & HA & HM & PI & PSP & RB & REPUT & KNOW \\
\hline HA & 1.000 & & & & & & \\
\hline HM & $\begin{array}{c}0.489 \\
{[7.874]} \\
(0.000)\end{array}$ & 1.000 & & & & & \\
\hline PI & $\begin{array}{l}0.540 \\
{[8.999]} \\
=(0.000)\end{array}$ & $\begin{array}{c}0.708 \\
{[14.062]} \\
(0.000)\end{array}$ & 1.000 & & & & \\
\hline PSP & $\begin{array}{c}0.291 \\
{[4.276]} \\
\Gamma(0.000)\end{array}$ & $\begin{array}{c}0.414 \\
{[6.385]} \\
(0.000)\end{array}$ & $\begin{array}{r}0.544 \\
{[9.091]} \\
(0.000)\end{array}$ & 1.000 & & & \\
\hline RB & $\begin{array}{l}0.541 \\
{[9.038]} \\
(0.000)\end{array}$ & $\begin{array}{c}0.503 \\
{[8.164]} \\
(0.000)\end{array}$ & 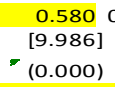 & $\begin{array}{l}.362 \\
{[5.452]} \\
(0.000)\end{array}$ & 1.000 & & \\
\hline REPUT & $\begin{array}{c}0.332 \\
{[4.943]}\end{array}$ & $\begin{array}{c}0.555 \\
{[9.365]}\end{array}$ & $\begin{array}{c}0.617 \\
{[11.010][8}\end{array}$ & $\begin{array}{c}0.524 \\
.644]\end{array}$ & $\begin{array}{c}0.316 \\
{[4.678]}\end{array}$ & 1.000 & \\
\hline KNOW & $\begin{array}{c}(0.000) \\
0.449\end{array}$ & $\begin{array}{c}(0.000) \\
0.539\end{array}$ & $\begin{array}{c}(0.000) \\
0.478\end{array}$ & $\begin{array}{c}(0.000) \\
0.321\end{array}$ & $\begin{array}{c}(0.000) \\
0.482\end{array}$ & 0.392 & \\
\hline & $\begin{array}{l}{[7.046]} \\
(0.000)\end{array}$ & $\begin{array}{l}{[8.984]} \\
(0.000)\end{array}$ & $\begin{array}{r}{[7.631]} \\
\text { (0.000) }\end{array}$ & $\begin{array}{r}{[4.764]} \\
(0.000)\end{array}$ & $\begin{array}{l}{[7.729]} \\
(0.000)\end{array}$ & $\begin{array}{l}{[5.977]} \\
(0.000)\end{array}$ & 1.000 \\
\hline
\end{tabular}

Furthermore, to examine the causal relationships among factors that potentially affect the purchase intention (PI) of individuals on Islamic pension program, regression analysis was performed with PI as the dependent variable and the other factors (KNOW, HA, HM, PSP, $\mathrm{RB}$ and REPUT) as independent variable. The regression results were summarized in Table 3. From a general perspective, the regression has a quite high goodness of fit, that is equal to $66.6 \%$. This indicates that $66.6 \%$ of PI behaviors can be explained together by KNOW, HA, HM, PSP, RB, and REPUT. Most of the independent variables, except knowledge, are also found to be positively and significantly affect the purchase intention.

Table 3. Regression results

\begin{tabular}{lrrrr}
\hline Independent Variable & Coefficient & Standard Error & T-statistics & Prob. \\
\hline Constant & 0.000 & 0.037 & 0.000 & 1.000 \\
KNOW & -0.014 & 0.050 & -0.286 & 0.775 \\
HA & 0.185 & 0.069 & 2.687 & 0.008 \\
HM & 0.409 & 0.069 & 5.891 & 0.000 \\
PSP & 0.219 & 0.065 & 3.357 & 0.001 \\
RB & 0.196 & 0.053 & 3.704 & 0.000 \\
REPUT & 0.286 & 0.068 & & 0.000 \\
\hline R-Squared & 0.666 & & & \\
Adj. R-Squared & 0.656 & & & \\
F-Statistic & 63.915 & & & \\
Prob. F-Statistic & 0.000 & & & \\
\hline
\end{tabular}

\section{Discussion}

From the descriptive findings shown in the previous section, several interesting insights could be revealed. First, only $3.3 \%$ of respondents are involved in Islamic pension program, which indicates that the penetration of Islamic pension funds in Indonesia is very low. Furthermore, $80 \%$ of the respondents do not know about the program, implying that the literacy rate for the Islamic financial product is also very low, as documented by OJK (2015). Yet, the results are quite consistent in the sense that the interest to participate in a financial product comes up along 
with the knowledge about the financial product. If one feels that he/she needs a financial product, then he/she will start thinking of having the product. The lack of literacy, in consequence, leads to the low penetration rate of Islamic pension funds in Indonesia.

Another interesting finding comes from the fact that half of respondents in Jakarta have not involved in any pension plans due to lack of knowledge. This is quite enticing considering the status of Jakarta as the capital of as well as the center of the financial industry in Indonesia. The fact is also true for Bandung. The majority of respondents who live in Bandung do not follow the pension plan due to ill-knowledge about the program.

Despite the results, the third descriptive finding indicates that around $72 \%$ of the respondents are interested to participate in the Islamic pension plans. Indeed, respondents in the two abovementioned cities have the greatest interest to participate in the Islamic pension program. Thus, it is argued that the demand for the Islamic financial product is relatively high in Indonesia. However, those who have converted their interest into buying behavior is very much circumscribed. The issue is also true for pension funds program in general, and not necessarily the Islamic one. Among the groups of occupations, entrepreneurs are the most ignorant in buying pension funds for the sake of preparing their old days. This might be related to their perspective that the formal pension program is merely designed for permanent workers (such as civil servants, military/police, state-owned employees or office workers). Indeed, it does not necessarily imply that entrepreneurs are not fretting about their old days. Instead, they tend to choose other ways in doing so, such as saving and investment in the real sector.

Furthermore, factor analysis shows that the marketing (HM) variable has the highest correlation with purchase intention (PI) on Islamic pension program. The knowledge factor (KNOW) is also found to have a high correlation with the halal marketing (HM). Overall, these results indicate that higher intensity of marketing/socialization activities will increase the consumers' knowledge of the product, and hence the purchase intention on Islamic pension program. This result is in line with the study of Awan et al. (2015) and Rahman et al (2015). In this regard, however, it is worth stressing that financial products are not the same as convenience goods which are usually marketed repeatedly by using an interesting artist or tagline. The latter are usually cheap and do not require experience of consumers to buy. However, in the former, consumer knowledge will greatly determine the involvement of consumers on the products. People who understand the functionality and benefits of the products will have a higher interest and be involved in using them. Therefore, regulators and pension funds should conduct more intense socialization/education, or marketing in general, to the public.

The reputation factor (REPUT) has a high positive correlation with marketing (HM), personal societal perception (PSP) and Purchase Intention (PI). A strong correlation with marketing shows that reputation can be communicated to the public through marketing/socialization activities conducted by pension funds institutions. Many reputable companies communicate their achievements through marketing activities. In pension funds, every achievement should be communicated to the public to enhance reputation. Furthermore, reputation of pension funds also has a strong positive correlation with purchase intention. A good reputation incentivizes consumers to participate in the pension program. In the case of pension funds, good reputations might come from the presence of good Sharia Supervisory Board in the organizational structure and the good performance of the pension funds per se, including strong capital, high return on investment, and the amount of pension benefits. 
The findings also show a strong correlation between religious belief (RB) and halal awareness (HA), marketing (HM), and Purchase Intention (PI). Religious belief is formed from several questions related to the beliefs of individuals on the existence of transactions prohibited by sharia such as riba, gharar, and maysir; individual commitment to consume and use only halal products; and beliefs to make preparation for the retirement age. Consumers with high religious belief tend to have a high halal awareness as well. They will ensure the halal status of a product before use or consume the product, be very sensitive to various marketing activities conducted by various so-called sharia companies, and be interested in the sharia jargon used by financial institutions and then go through the claim through involving in the Islamic products. They will also have a high intention on the Islamic pension programs and avoid conventional retirement programs. These results are in harmony with the findings of previous studies such as Shaari and Arifin (2009) and Schneider et al., (2011).

On the regression results, there are some interesting findings. First, all independent variables except knowledge (i.e. religious beliefs, halal awareness, reputation of pension funds, personal societal perception and halal marketing) have a significant positive effect on the purchase intention. Hence, an increase in the independent variables will also increase the purchase intention for Islamic pension funds despite of different influence magnitude of each factor. Second, halal marketing has the greatest marginal effect to purchase intention than the others. This implies that better marketing of Islamic pension funds will effectively increase purchase intentions on the programs. Surprisingly, the knowledge factor does not directly affect a Muslim's intention to participate in the Islamic pension program. These findings indicate that people who just aware about Islamic pension fund are not necessarily interested in trying or buying the product. Thus, the strategy of increasing purchase intention on Islamic pension program by boosting consumers' knowledge is not enough and must be followed by strategies to translate the knowledge into an actual buying behavior.

\section{Conclusion}

This study is an attempt to explore the demand of Islamic pension funds as well as to examine the determinants of the purchase intention of the program. The purchase intention was measured through using modified halal purchase intention framework that was usually used in the halal marketing related studies. To this end, this study conducted a survey and utilizes primary data from 200 respondents across six big cities in Indonesia, namely Jakarta, Bandung, Makassar, Balikpapan, Surabaya and Medan.

The results confirmed the previous findings regarding the low penetration of pension funds in Indonesia. Neither conventional nor Islamic pension plans are commonly subscribed by most Indonesians. Only 3\% of respondents have participated in the Islamic pension program due to the lack of knowledge and unawareness to participate in the same. However, about $72 \%$ of respondents expressed their interest to participate in the Islamic pension funds. In addition, the factor analysis and regression analysis suggested that halal awareness, halal marketing, personal societal perception, religious belief, and reputation are positively priced on the purchase intention and demand of Islamic pension funds.

Some policy implications might be derived from the results. OJK as a regulator must devise the effective ways to improve knowledge and awareness of the consumers about the pension 
programs. The role of pension fund institutions in providing education and socialization per taining to the importance of pension programs to various layers of society, especially those engaged in the informal sector, should also be enhanced. Moreover, entrepreneurs can be the main targets, owing to the fact that many of them are not interested, not knowing, or unthinkable to participate in Islamic pension program. Finally, further researches are also expected particularly on the exploration of the most effective ways to educate the markets.

\section{References}

\section{Journal article}

Alam, S. and Sayuti, N. (2011), "Applying the theory of planned behavior (TPB) in Halal Food purchasing", International Journal of Commerce and Management, Vol. 21 No. 1, pp. 8-20.

Altaf, M., Iqbal, N., Mokhtar, S.S.M and Sial, M. H. (2017) "Managing consumer-based brand equity through brand experience in Islamic banking", Journal of Islamic Marketing, Vol. 8 Issue: 2, pp.218-242.

Awan, H.M, Siddiquei, A.N. and Haider, Z. (2015). Factors affecting Halal purchase intention - evidence from Pakistan's Halal food sector. Management Research Review, 38 (6).

Azam, A. (2016), “An empirical study on non-Muslim's packaged halal food manufacturers: Saudi Arabian consumers' purchase intention”, Journal of Islamic Marketing, Vol. 7 Issue: 4, pp.441-460.

Hassan, S.H and Harun, H, (2016) "Factors influencing fashion consciousness in hijab fashion consumption among hijabistas", Journal of Islamic Marketing, Vol. 7 Issue: 4, pp.476494

Mayer, C., Schoors, K. and Yafeh, Y. (2003). Sources of Funds and Investment Activities of Venture Capital Funds: Evidence from Germany, Israel, Japan, and the UK. NBER Working Paper Series.

Panetta, I.C. (2006). Financial Markets Trend: Ageing and Pension System Reform. MPRA Paper 18391.

Rahman, A.A., Asrarhaghighi, E. and Rahman, S.A. (2015) "Consumers and Halal cosmetic products: knowledge, religiosity, attitude and intention", Journal of Islamic Marketing, Vol. 6 Issue: 1, pp.148-163.

Schneider, H., Krieger, J. and Bayraktar, A. (2011), "The impact of intrinsic religiosity on consumers' ethical beliefs: does it depend on the type of religion?Acomparison of Christian and Moslem consumers in Germany and Turkey", Journal of Business Ethics, Vol. 2 No. 2, pp. 319-332. 
Shaari, J.A.N. and Arifin, N.S.M. (2009), "Dimension of Halal purchase intention: a preliminary study", American Business Research Conference, 28-29 September, New York, NY.

\section{A book}

Arafa, K. (2014). Pension Schemces- The Silver Lining of Collective Pooling. Can Sharia Compliant Pension Scheme Give a Much Needed Boost to The Islamic Asset Management Sector. Global Islamic Asset Management Report. Lipper and Thomson Reuters.

Blake, D. (2006). Pension Finance. Wiley: West Sussex.

Chapra, M. U (2008), The Islamic Vision of Development in the Light of the Maqasid alShariah, Jeddah: IRTI-IDB

El-Ashker, A.A.F and Wilson, W. (2006), Islamic Economics: A Short History. Leiden: Brill.

Field, A. (2009). Discovering statistics using SPSS. London: SAGE Publications.

Hair, J.F. (2013). Multivariate Data Analysis. Upper Saddle River, N.J.: Prentice Hall

Manjoo, F.A. (2012). An Appraisal of Longevity Risk: Conventional and Islamic Perspective. Kuala Lumpur: ISRA.

OJK (2014). Pension Funds Statistics 2014. Otoritas Jasa Keuangan: Jakarta.

OJK (2015). Peraturan Otoritas Jasa Nomor 3/POJK.05/2015 tentang Investasi Dana Pensiun. Otoritas Jasa Keuangan: Jakarta.

Scott, L. David. (1988). Wall Street Words. Houghton Mifflin: Boston. 